\title{
Change and metrics in Guhtura-Niillas' luohti
}

\section{Introduction}

Yoik (Sámi juoiggus) is an exclusively national musical expression of the Sámi people, though a similar type of singing is common to Arctic peoples from Northern Fennoscandia to Eastern Siberia. The traditional yoik is an unaccompanied chant with special kinds of social functions in the Sámi society. From the concept of yoik, which is a common term for the phenomenon, is derived luohti, referring to a particular chanting performance. It includes the music and the lyrics as well as the performors gestures and mimics. Luohtis can be divided to different categories depending of the described object i.e. persons, places and animals, specially dogs and reindeer. (Aikio, S. et. al. 1994, 104)

In this article I will apply a historical perspective to the Northern Sámi yoik which has not been widely employed in the previous research. My main focus is on GuhturaNiillas' luohti which has been passed from father to son in the family called Magga, living in the village of Guhtur by the River Ivalo in Northern Finland.

I shall examine how this particular luohti changes when different people from two generations, Guhtura-Niillas (1868-1931) and Guhtura-Niillas Ante ${ }^{1}$ (1910-1982) are yoiked with the same luohti. Furthermore, I shall look for change in the metrical systems in different versions of Guhtura-Niillas' luohti. With this method I want to focus on finding how the melody and text of one luohti can be varied during different performances.

The main sources are two historical recordings of this luohti which were made by Erkki Ala-Könni in 1961. There are four existing examples of Guhtura-Niillas' luohti collected in 1904-1905 by Armas Launis, as well. I will make a comparison between these six historical versions of one luohti.

\section{The traditional Sámi singing - yoik}

\subsection{The reindeer Sámi people of Eastern-Finland}

The district of Inari got most of its reindeer Sámi people during the second half of the 19th century when some 15 families moved from Norway and Enontekiö (see Fig. 1.). The origin of this migration was the closing of the boarders between Russia (The Grand Duchy of Finland) and Denmark-Norway in 1852 and between Russia and

\footnotetext{
${ }^{1}$ In the Sámi language the genitive suffix is $a$ added to the end of a word. Guhtura-Niillas means Niillas from the village of Guhtur or the son of a person named Guhtur.
} 
Sweden in 1889. (Aikio, M. 1987, 17-19)

The reindeer Sámi families of Enontekiö had traditionally spent winters in the mountain area in Finland and the summertime on the coast of the Northern Sea in Norway. According to the treaty of Strömstad 1751 they had a right to herd freely from one country to another and this right was maintained after Finland became part of Russia in 1809. But when the herds of the Sámi began to grow and Finnish and Norwegian new settlers competed for the same lands these two ethnic groups were drawn into the conflict, as well. (Tikkanen 1966)

The local officers were not able to solve these problems. The fact that the Russian borders which had been moving to the West in early 19th century were seen as a threat in the West, especially in Britain, did not help the situation. After long and unsuccesful negotiations, the Finnish officers closed the border in 1852 and the herding across the border was forbidden. The reindeer Sámi families had to choose where to live permanently. (ibid.) According to Niillas Magga (An interview 1961) a A three men expedition group was sent from Enontekiö to the East to look for new herding lands and the Inari-district was chosen as the best new herding land.

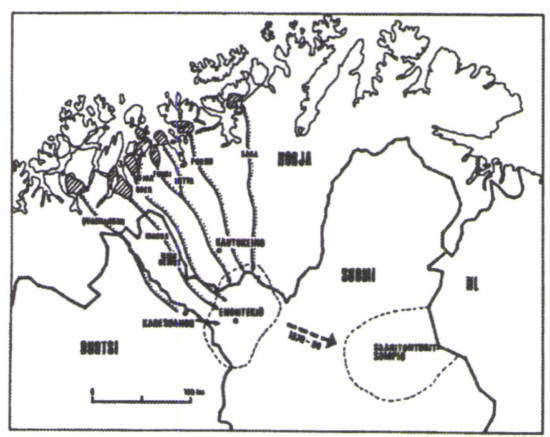

Figure 1. The map shows the migration of the reindeer Sámi people of Northern Scandinavia in general. Source: Aikio, M. 1987, 18.

A family called Magga was one of the families who migrated to the Sompio-Siikaselkä district in Eastern Finland at the end of the 1880s. In 1899 Guttorm Magga, Karin Nikodemus and Guttorm's som Niillas Magga (Guhtura-Niillas) settled by the river Ivalo in Southern Inari district. Later this settlement grew to be the village of Guhtur ${ }^{2}$.

\subsection{The traditional yoik}

The traditional Sámi yoik differs conceptually from the Western song tradition in that when a Westerner sings of someone or something, a yoiker yoiks someone or something as a whole. It can be said that when a person is yoiked he or she is called out from the collective memory of the performer and other participants ${ }^{3}$.

During the performance of luohti, the story of a person is recalled. The yoiker

\footnotetext{
${ }^{2}$ Officialy Guhtur is a part of village called Paadar in the district of Inari (Nahkiaisoja 1995). For more information about Guhtur see Jouste 1997; Magga 1994.

${ }^{3}$ In a famous book Muittalus samid birra (1910) written by a mountain Sámi Johan Turi, yoik is described as a way to recall people or certain places.
} 
leads the telling of the story by giving hints of the character or some important happening in the objects life. Often it is not necessary to reveal much about the character of the author of the luohti because it is expected that the participants are acquainted with him or her. Sometimes it is enough that some characteristic features of the object are described with the timbre of the voice and everyone recognises the object. It is common that people know the melodies of each others luohtis.

In the performance of a traditional luohti it is necessary to have a strong emotional charge for the person which is yoiked. These emotions can vary from admiration, affection to pity or irony, mockery, envy, jealousy, fear, etc. According to Edström $(1978,133-140)$ the social functions of the traditional yoik in the traditional Sámi society can be described as: 1) a reinforcement of memory 2) an emotional function 3) communication 4) entertainment 5) relaxation and 6) symbol function.

The traditional yoik has preserved its place in the Sámi society, although there has been some change in this over the past few decades as the international cultural and economical systems have become integrated into the Sámi region. Every Sámi does not know how to yoik anymore but yoik has had an effective impact on all Sámi music during the past three decades (Lehtola 1997, 106).

\subsection{Some problems in the research on the yoik}

Though the Sámi people are one of the most academically studied peoples in the present history many problem areas still remain. Studies on Sámi people and yoik have tended to concentrate either on cultural analysis or musical analysis, rarely combining these aspects, though this is the main premise of ethnomusicology.

The main problem is that for Westerners the yoik seems to use musical expression in a large sense similar to the concept of Western music. But 'pure' musical level is just a part of the meaning of the yoik. The meaning of the yoik can not be interpreted from musical elements alone. The same yoik can achieve different meanings depending on the place and audience. Performing traditional luohtis for example to a collector who does not know the objects of yoiks may cause a problematic situation to a yoiker.

There are some fine examples in the Ala-Könni collection where the collector asks the yoiker to resitate the meaningful words of an luohti. For most of the yoikers this kind of interpration of a luohti is unrational and it is hard to tell the words of a luohti separately from the melody. Yoikers often end up telling the life story of the yoiked person to the collector. The collector, without a knowledge of the Sámi language seems often to be satisfied to the given the answers.

If the communicative side of the yoik is emphasised there is a danger of turning the perspective of research upside down. For the yoiker the yoik is communication in the present though he or she can also refer to the past. For the researcher, once happened yoiking can easily be turned into merely a historical event restored from the past from which the chosen aspects are studied (see Table 1.). So, the yoiker and the analysist have a different perspective to a certain luohti. This way the meanings of the yoik can be lost and the yoik loses its original communicational and emotional functions and becomes 'pure' music. 
Table 1. The difference in the yoikers view and the researchers view.

\begin{tabular}{|c|l|c|}
\hline The yoikers view: & \multicolumn{1}{|c|}{ Yoik: } & The researchers view: \\
\hline \multicolumn{1}{|c|}{ To the past } & \multicolumn{1}{|c|}{ Elements of a certain luohti } & \multicolumn{1}{|c|}{ In the present } \\
\hline $\begin{array}{l}\text { Making a comment } \\
\text { to the past. }\end{array}$ & $\begin{array}{l}\text { * Melody } \\
\text { * Text } \\
\text { * Rhythm } \\
\text { * Metrics }\end{array}$ & $\begin{array}{l}\text { Analysing a certain } \\
\text { luohti in the present. }\end{array}$ \\
\hline Producing new. & $\begin{array}{l}\text { * Ornamentation } \\
\text { * Special singing techniques } \\
\text { * Local differences }\end{array}$ & $\begin{array}{l}\text { Individual style vs. col- } \\
\text { lective style tradition }\end{array}$ \\
\hline \multicolumn{1}{|c|}{ Meanings of yoik } & To the past \\
\hline $\begin{array}{l}\text { Making a comment } \\
\text { to the present. }\end{array}$ & $\begin{array}{l}\text { * Communication } \\
\text { * Emotions (admiration, affection, pity, } \\
\text { irony, mockery, envy, jealousy, fear, etc.) } \\
\text { * Other social functions (a reinforcement } \\
\text { of memory, entertainment, relaxation, } \\
\text { symbol function) }\end{array}$ & $\begin{array}{l}\text { Restoring the once } \\
\text { happened yoiking from } \\
\text { the past }\end{array}$ \\
\hline
\end{tabular}

Furthermore, the traditional yoik is somehow distant from Western music and existing methods of analysis are often insufficient. The following aspects in yoik research have not been studied sufficiently:

1) The background information of the object of the luohtis and yoiker is often insufficient.

2) The whole luohti with all the variations of the melody are missing. In yoik research there has been too heavy interest in large corpuses and defining typical melodytypes. There has also been a great interest in defining scales rather that explaining how the melody works.

3) The ornamentation of the melody and the special singing technics of the yoik have not been studied well enough.

4) The whole text of the yoik is often missing usually because the researchers have not been well acquainted with the Sámi language.

In general, musical analysis of the traditional yoik has often been made without a time perspective. Certain luohtis and their objects are analytically considered as stable, without any change.

\section{The luohti of the family of Magga}

\subsection{Guhtura-Niillas' luohti}

Guhtura-Niillas was born in Enontekiö in 1868 to a family of Sámi reindeer herders. Niillas lived in a traditional herding Lapphut society until the end of the 1880s, when the family moved to the Sompio-Siikaselkä district in Eastern Lapland. In 1899 they settled in Southern Inari, where they founded the village of Guhtur. Guhtura-Niillas got married in 1902 to Priita Helena Morottaja and they had five children. Guhtura-Niillas died in Guhtur in 1931. He is considered to have founded the village when he built a 
large house in which all the inhabitants of the village lived until the mid 1940s.

Erkki Ala-Könni recorded Guhtura-Niillas' luohti ${ }^{4}$ in 1961. Guhtura-Niillas was yoiked by his son Niillas Niillas (Niillas Magga b.1904 d.1968). In the recording, Niila first performs the luohti and then he is asked to tell the exact words of the luohti. Niila tells briefly the story of his father, i.e. he explains the luohti to the collector who did not know Guhtura-Niillas.

\section{1) The text}

In the text of this luohti Guhtura-Niillas is memorialized in the following way:

Guhtura Niillas was. A long time ago he lived on the banks of the Ivalo River. Guhtura was. Niillas was.

The name Guhtura-Niillas suits very well to the rhythm of the melody (Guh-tu-ra -Nil-la lei-joo) and it is very likely that the luohti has got its rhythm and melody from the rhythm of the object's name. It is notable that the meter of the text changes when it is sung or yoiked. Guh-tu-ra, with the accent on the first syllable changes to Guh-tuu-ra, with the accent on the second syllable when it is sung.

The Guhtura-Niillas' luohti consists of five parts. Four of these parts begin with a text line. Only the fourth has no text and only filling syllables.The text lines begin with a word which has three syllables and the second word has two syllables. After this there are another two syllables in the melodyline, but only the first syllable has a meaning: Guh-tu-ra Nil-la lei joo; Av-vii-la guo-ras dai joo.

The filling syllables form most of the text of the Guhtura-Niillas' luohti. Some filling syllables have a meaning though the main purpose of these syllables is to let the melody continue. It seems that filling syllables also gives the yoiker a chance to use a more descriptive vocal style. In any case, this is the part that differs the most in different performances. Also it is common to vary the rhythm and the melody during yoiking with the filling syllables.

The filling syllables found from Guhtura-Niillas' luohti can be divided to three categories shown in table 2. The most common syllable is non (nun) or noo (nuu) and they do not have any specific meanings but a yoiker gives to them different meanings with different sounds and timbres. Vel (-la) means still, once again, more. Go means when or as. Joo means yes or yeah!

Table 2. Three categories of the filling syllables and their meanings found from Guhtura-Niillas' luohti.

\begin{tabular}{|l|l|}
\hline \multicolumn{1}{|c|}{ Filling syllables: } & \multicolumn{1}{c|}{ Meaning: } \\
\hline $\begin{array}{l}\text { 1. Non-noo, nun-nuu, } \\
\text { lai-laa, lul-luu, etc. }\end{array}$ & $\begin{array}{l}\text { These syllables itself do not have specific meanings but a yoiker } \\
\text { gives to them different meanings with different sounds and timbres. }\end{array}$ \\
\hline 2. Vel (-la), joo, etc. & $\begin{array}{l}\text { Words have meanings but they are used rather freely in the text and } \\
\text { the real function is to keep the 'conversation' going on. }\end{array}$ \\
\hline 3. Go & $\begin{array}{l}\text { It means 'when' or 'like' and often it is placed in structurally im- } \\
\text { portant places in the text }\end{array}$ \\
\hline
\end{tabular}

Another function of the filling syllables is to complete the text lines in which the words

\footnotetext{
${ }^{4}$ Tape A-K 544/5, Collection of the archives of the Department of Folk Tradition. University of Tampere.
} 
do not have enough syllables. In the second text line of the Guhtura-Niillas'yoik, there is originally a four-syllable line (Do-lin áig-ge) which is supplemented with a filling syllable go so that the line becomes a five-syllable: Do-lin go áig-ge. In the last text line both the words Nilla and lei are completed with a filling syllable: Nil-la go leijoo.

It is notable that filling syllables seem to have specific places where they can be found in Guhtura-Niillas' luohti. For example, the syllable go is found only in place of the third syllable. The syllable joo is always connected to a one-syllable word (lei-joo or dai-joo).

Text example 1. The text and translation of Guhtura-Niillas' yoik. Transcription by Marko Jouste and Siiri Miettunen.

\begin{tabular}{|c|c|c|c|c|c|c|c|c|}
\hline \multicolumn{8}{|c|}{ The text } & \multirow{2}{*}{$\begin{array}{c}\text { English translation } \\
\text { Guhtura Niillas was }\end{array}$} \\
\hline 1 & Guh- & $t u-$ & $r a-$ & Nil- & la & lei & joo & \\
\hline 2. & vel- & la & go & non- & non, & non- & noo & (filling syllables) \\
\hline 3. & non- & noo, & go & non- & non, & non- & noo & “ \\
\hline 4. & non- & noo, & go & non- & non, & non- & noo & “ \\
\hline 5. & Do- & lin & go & áig- & ge & dai- & joo, & A long time ago he lived \\
\hline 6. & lei & joo, & go & vel- & la & nun- & nuu, & (filling syllables) \\
\hline 7. & nun- & nuu & go & \multicolumn{2}{|c|}{ nuu- nu, } & nun- & nuu & “ \\
\hline 8. & $A v-$ & vii- & $l a$ & guo & ras & dai & joo, & $\begin{array}{c}\text { On the banks of Ivalo } \\
\text { River }\end{array}$ \\
\hline 9. & lei & joo & go & vel- & la & nun- & nuu & (filling syllables) \\
\hline 10. & No & non- & no & \multicolumn{2}{|c|}{ noon- no, } & non- & noo & (filling syllables) \\
\hline 11. & no & non- & no & \multicolumn{2}{|c|}{ noon- no, } & non- & noo & “ \\
\hline 12. & non- & noo & go & \multicolumn{2}{|c|}{ noon- no, } & non- & noo, & “ \\
\hline 13. & no & noo & go & \multicolumn{2}{|c|}{ naa- no, } & non- & noo & “ \\
\hline 14. & non- & noo & go & \multicolumn{2}{|c|}{ non- no, } & non- & noo, & “ \\
\hline 15. & Guh- & $t u-$ & $r a$ & \multicolumn{2}{|c|}{ lei-joo, } & vel- & la & Guhtura was \\
\hline 16. & Nil- & $l a$ & go & \multicolumn{2}{|c|}{ lei-joo, } & vel- & laa, & Niillas was \\
\hline 17. & nun- & nuu & go & \multicolumn{2}{|c|}{ noo- no, } & nun- & nuu, & (filling syllables) \\
\hline 18. & nun- & nu & go & \multicolumn{2}{|c|}{ nun- nu, } & nun- & nuu, & “ \\
\hline 19. & nun- & nuu & go & \multicolumn{2}{|c|}{ nun- nu, } & nun- & nuu & “ \\
\hline
\end{tabular}

\section{2) The melody}

The melody of Guhtura-Niillas' luohti consists of three motives: the beginning motive 
B (g-h-g), the centre motive C (g-h-c-d-c) and the tail motive T (d-c) (see note ex. 1a.) The last note of the beginning motive is also the first note of the centre motive. The centre motive is the most important part of the melody. It is present in every repeated melody line. The beginning and the tail alternate so that the tail motive replaces the beginning motive. A melodic line cannot end with a tail motive when the next melodic line starts with a beginning motive. The luohti ends also on the last note of the centre motive.

The durations of the note values are problematic if their lengths are treated as absolute ones. I have divided the notes into two categories ${ }^{5}$. The basic pulse is found from the short notes $(S)$ of which the majority of the melody consists. In contradiction to the short notes there are long notes (L) the exact duration of which vary from double duration to triple duration of the short note. In fact the actual sound is not held the whole time but rather it is a question of the time that is used to occupy the space before the next note. There is one exception of two short notes (SS) turning to one and one half short notes $\left(\mathrm{SS}^{1}\right)$ so that the four 1/8-rhythm changes to three $1 / 8$ - rhythm. This can be found in lines number 7 and 10-19.

When these principles are applied to the interval structure of the melody, some of the variations of the melody can be explained as well. Accordingly, the notes can be analysed as high pitched or low pitched ones. There can be substantial variation of the intervals even during one performance.

There are some variations in the pitch of the notes in melody. When the exception of the first line is excluded, all the variations are found either in the beginning motive or the tail motive.

Melodically the tail motive cannot be analysed as a part of the beginning motive though metrically they fit very well to each other. This presumption is based on the thought that a yoiker does not mix the ground note or finalis $(\mathrm{g})$ with other notes. Therefore, there cannot exist a note $\mathrm{d}$ or $\mathrm{c}$ instead of a note $\mathrm{g}$.

\section{3) The metrical systems in yoik}

As in any transcription, the metrical system presented in a note transcription is a result of an analysis and interpretation of the analyst. Furthermore, it is known that many different notations are needed to show different aspects of one piece of music. In order to avoid a limited perspective to Guhtura-Niillas' luohti and to explain the existing complex metrical system, I have made three different notations: 1) according to the similar melodic patterns (note ex. 1a) 2) according to the rhythm (accentuation) of the yoiker (note ex. 1b) and 3) according to the meter of the text (note ex. 1c).

In the first notation the melodic motives are written in vertical paradigms. The beginning motive consists of three short notes (SSS), from which the third is the first of the centre motive of the luohti. The centre motive has both short, long and half short notes (SSS SL or SSS ${ }^{1}$ SL). The tail motive has only short notes (SS) (see table 3 and note ex. 1a.)

\footnotetext{
${ }^{5}$ For further information about the system used here see Lippus 1995; Niemi 1998, 27-29.
} 

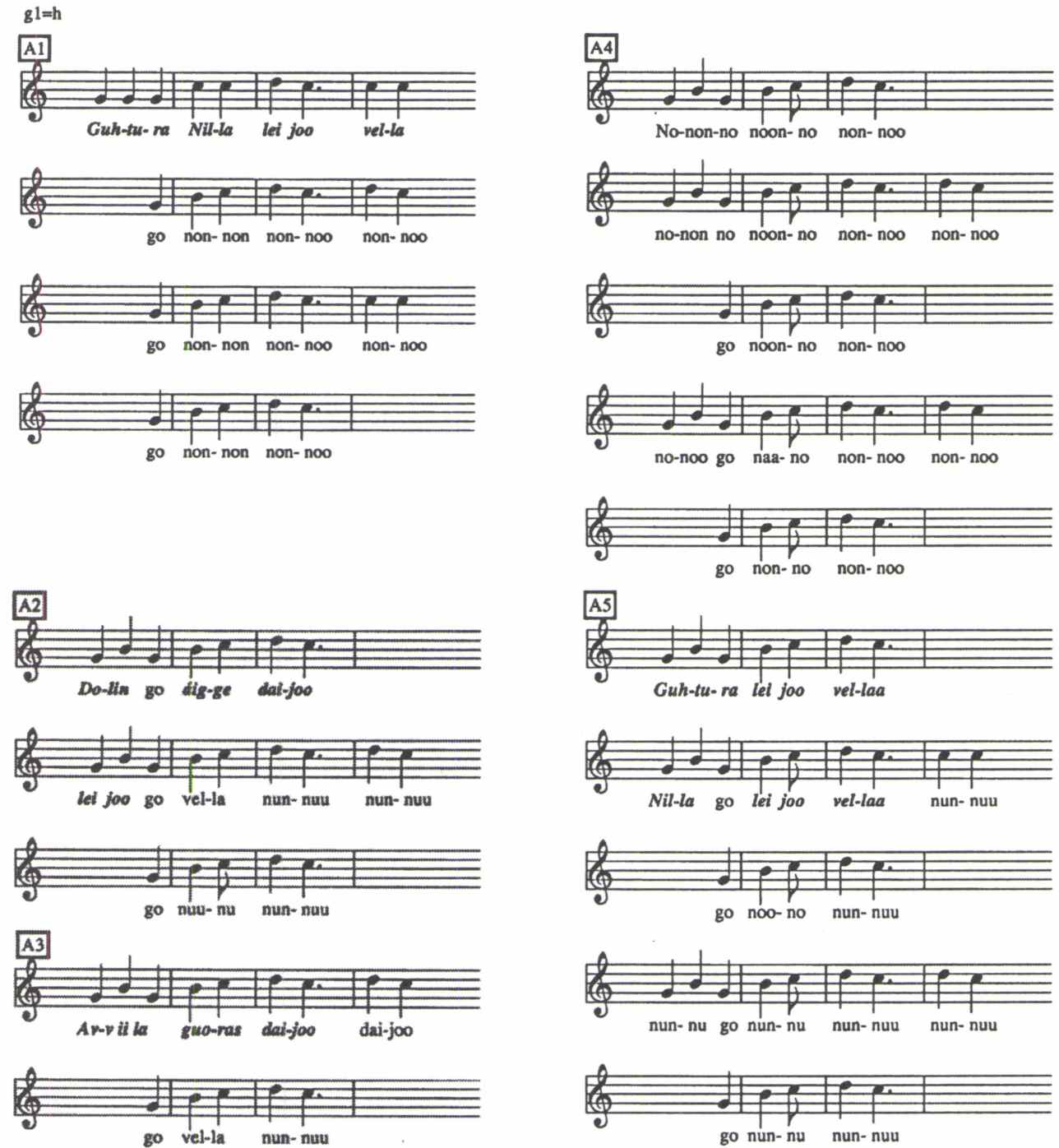

Note example 1a. Guhtura-Niillas' luohti yoiked by Guhtura-Niillas' Niila. Song transcription by Marko Jouste from a recording by Erkki Ala-Könni. Tape A-K 574/6, 1961. The archives of the Department of Folk Tradition, University of Tampere. 
Table 3. The possible syllable lines on different melody lines.

\begin{tabular}{|l|l|l|l|l|}
\hline \multicolumn{1}{|c|}{ Lines: } & \multicolumn{4}{c|}{ Note duration's: } \\
\hline & B & C & T \\
\hline $1,6,8$ & SS & SSS & SL & SS \\
\hline 5 & SS & SSS & SL & - \\
\hline 10,15 & SS & SSS $^{1}$ & SL & - \\
\hline 2,3 & - & SSS & SL & SS \\
\hline 4,9 & - & SSS & SL & - \\
\hline $7,12,14,19$ & - & SSS $^{1}$ & SL & - \\
\hline $11,13,16$ & SS & SSS $^{1}$ & SL & SS \\
\hline 17,18 & - & SSS $^{1}$ & SL & SS \\
\hline
\end{tabular}

According to the text line, the meter of the luohti seems to be more simple. All the lines can be analysed as SSS SS SL.

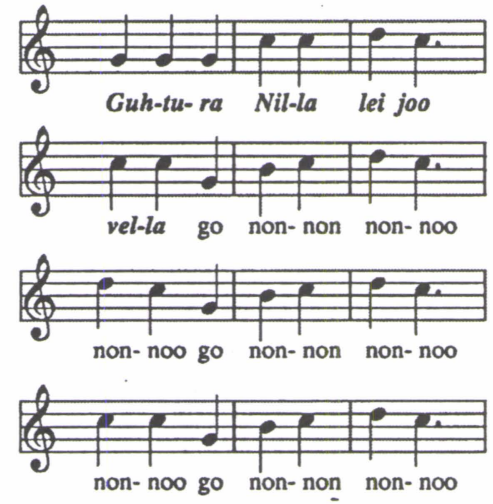

Note example 1b. Guhtura-Niillas' luohti (1st part) notated according to the meter of the text.

The yoiker accentuates his performance in the following way:

\section{(S) / SSSS / SLS}

It is clear that the yoiker has a pulse and he begins the luohti with an upbeat. Further more on every second $4 / 4$ bar he is syncopating his own basic pulse (see note ex. 1c.). 

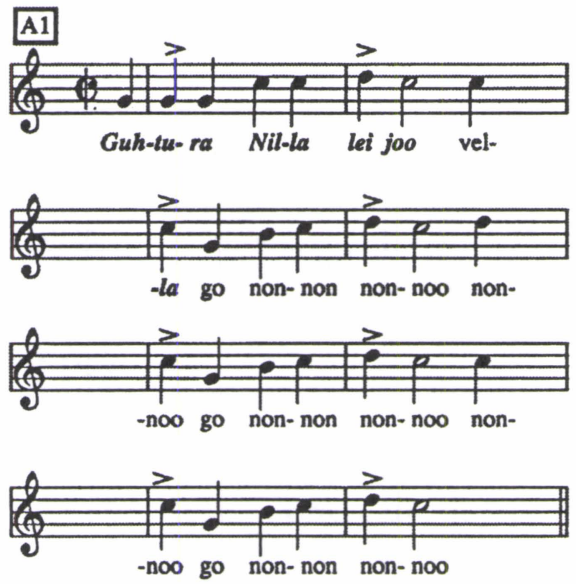

Note example 1c. Guhtura-Niillas' luohti (1st part) notated according to the yoiker's accents.

The most interesting thing is how these three overlapping meters work together. The key question is what happens when the yoiker moves from one line to another. At this point, which I call the joint there is the greatest inconsistency of different meters (see note ex. 1d.).

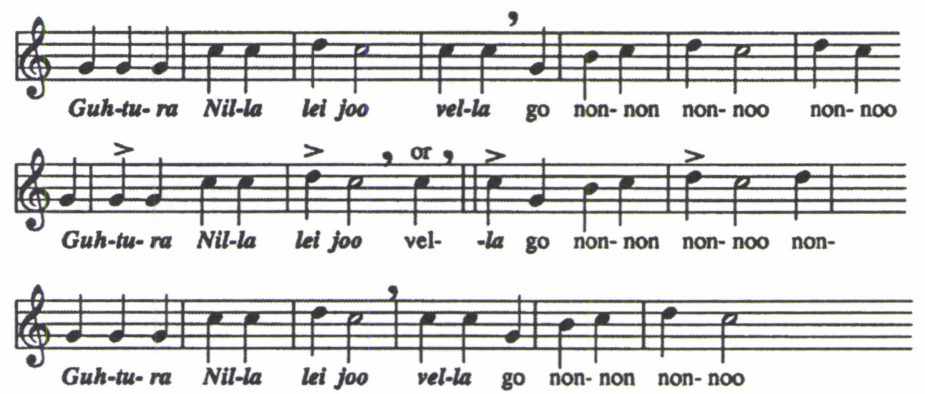

Note example 1d. Three different meters in the beginning of the Guhtura-Niillas' luohti.

\subsection{Guhtura-Niillas'Ante's luohti}

Guhtura-Niillas'Ante (1910-1982) was the. youngest son $^{6}$ of Guhtura-Niillas. Later Ante was known as a rich reindeer owner who gathered a large herd in the 1940s and 1950s. He inherited his father's earmark, though Niillas had lost most of his reindeers during the era of reindeer plague epidemics in the 1910s. Followed by the hard times

\footnotetext{
${ }^{6}$ One daughter was born after Ante but she died at the age of four in 1916.
} 
of the First World War and the hunger in Northern Finland, Niillas newer fully recovered from the loss of his herd. Niillas' wife and youngest daughter died as well in the 1910s.

Erkki Ala-Könni recorded Guhtura-Niillas'Ante's luohti ${ }^{7}$ in 1961. Guhtura-Niillas was yoiked by Uula Aikio ${ }^{8}$ from Ivalo and Antti Ruotsala from Nunnanen. In the recording they first perform the luohti together and then Antti Ruotsala tells briefly the story of Ante who was 51 years old at that time.

\section{1) The text}

Ante's grandfather, Guhtura (1843-1899), was rich as well and in a way Ante is considered to continue the work of Guhtura rather than Ante's father Niillas. This is said clearly in text of the luohti: Even in the old days they had been clanging - the great bells. And they are still clanging in Guožurbuollamis. Guožurbuollamis is a place near the village of Guhtur, and Ante's reindeers were herded there.

Text example 2. The text and translation of Guhtura-Niillas'Ante's luohti. Transcription by Marko Jouste and Siiri Miettunen.

\begin{tabular}{|l|l|l|l|l|l|l|c|}
\hline \multicolumn{7}{|c|}{ The text } & English translation \\
\hline Do- & lin & jo (n) & ái- & ge (n) & dat & joo & Even in the old days \\
\hline leid- & je & joo & ska- & lai- & dan & joo & they had been clanging - \\
\hline lol- & lol & go- & lol & lol- & lol- & loo & (filling syllables) \\
\hline Dat & joo & go & stuor- & ra & biel- & lu & the great bells. \\
\hline non- & non & go & non- & non & non- & noo & (filling syllables) \\
\hline non- & no & go & non- & no & non- & noo & \\
\hline & & & & & & & “ \\
\hline Gal- & dat & joo & ska- & lai- & dit & joo & And they are \\
\hline Dal- & ge & joo (n) & ái- & ge & vel & joo & still clanging \\
\hline Dai- & joo & go & Guo & žur & buol- & la- & in Guožurbuollamis. \\
\hline mis & joo & go & lol- & lol & lol- & loo & (filling syllables) \\
\hline
\end{tabular}

In this version, the text is placed in different places than in Guhtura-Niillas' luohti. The text lines begin with two-syllable words (do-lin, leid-je, galgat, dal-ge). The keywords of the luohti are at the end of each melodic phrase rather than in the beginning, as it was the case in Guhtura-Niillas' luohti. The first impression of Ante's luohti is coloured by the rhythm of two-syllable words. This is a fine example of a case where the words of the text can be altered in relation to melodic phrase. The meter of the text is not changed. This is made possible by the filling syllables which complete the text. Also the word Guožurbuollamis is divided into two text lines.

The filling syllables are non-noo, lol, loo, joo and go. They have the same func-

\footnotetext{
${ }^{7}$ Tape A-K 547/3, Collection of the archives of the department of Folk Tradition. University of Tampere.

${ }^{8}$ Son of famous yoiker Kaapin Jouni (Jouni Aikio).
} 
tions as in Guhtura-Niillas' luohti. The filling syllable go is found again in place of the third syllable. The filling syllable joo is also found in place of the third syllable, but in these cases it is always connected to the previous word (do-lin-joo, leid-je-joo, galgatjoo, dal-ge-joo). The filling syllables help to adjust a new text to an already existing melody. This way the filling syllables also help improvisation.

\section{2) The melody}

The melody of Guhtura-Niillas'Ante's luohti is quite similar to Guhtura-Niillas' luohti, though some minor differences exist. The beginning motive is g-a-g instead of g-h-g, as in Guhtura-Niillas' luohti. The centre motive is g-a-h-d-c instead of g-h-c-d-c. The tail motive is h-d instead of d-c or c-c.

\section{3) The metrical systems in yoik}

In Ante's yoik there is a similar metric system to Niillas' yoik. This supports the notion of the flexible joint which connects two text lines and the melodic lines together. Also the yoikers of Ante's yoik make rhythmical accents in the same place as in Niillas' yoik. The possible meters of different lines according to the melody are shown in table 4.

Table 4. The possible syllabic combinations of different melody lines.

\begin{tabular}{|l|c|c|c|c|}
\hline \multicolumn{1}{|c|}{ Line: } & \multicolumn{4}{|c|}{ Note duration's: } \\
\hline & B & \multicolumn{2}{|c|}{ C } & T \\
\hline $1,3,5,7$ & SS & SSS & SL & SS \\
\hline $2,4,6,8,10$ & - & SSS & SL & - \\
\hline
\end{tabular}



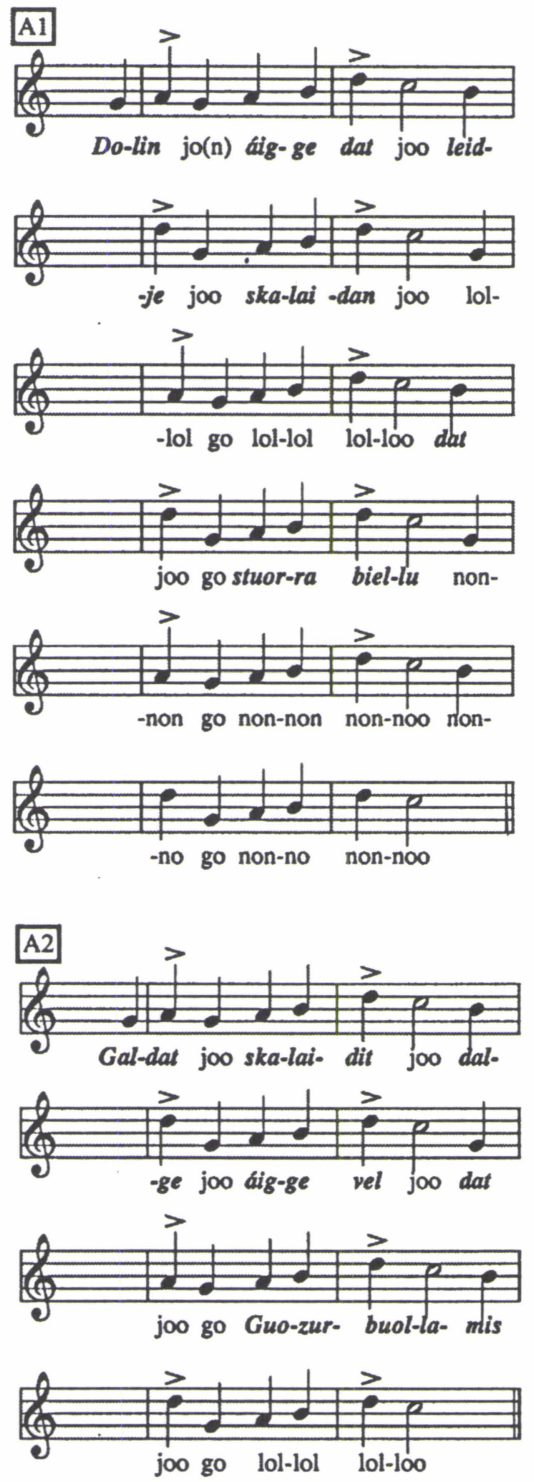

Note example 2. Guhtura-Niillas'Ante is yoiked by Antti Ruotsala and Uula Aikio. Song transcription (according to the yoikers accents) by Marko Jouste from a recording by Erkki Ala-Könni. Tape A-K 547/3, 1961. The archives of the Department of Folk Tradition, University of Tampere.

\subsection{Comparison of the Guhtura-Niillas' luohti and Guhtura-Niillas'Ante's luohti}

\section{1) Comparison of the texts}

There is a great difference in the way Guhtura-Niillas and Guhtura-Niillas'Ante are described in the text. Guhtura-Niillas is described as living beside the river of Ivalo. 
Guhtura-Niillas'Ante is not mentioned by name. Everyone knows the melody of the family and there is no misunderstanding when it is said that the described person is rich (he has a big herd of reindeers, i.e. the great bells). Ante's grandfather, Guhtur also had a big herd and this is mentioned in Ante's yoik (In the old days...).

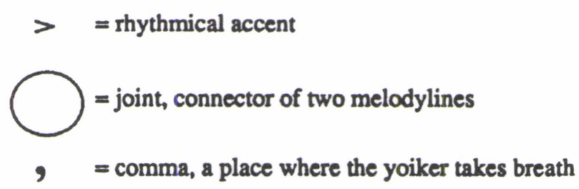

Guhtura-Niillas' luohti written according to the meter of similar melodic lines:

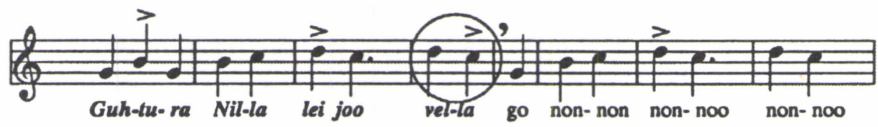

Guhtura-Niillas' luohti written according to the meter of the yoiker's accents:

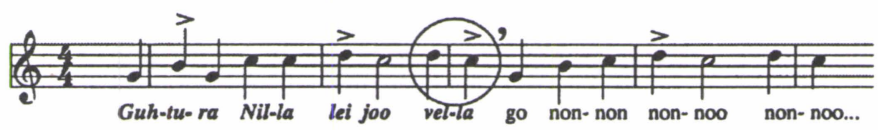

Guhtura-Niillas' Ante's luohti written according to the similar melodic lines:

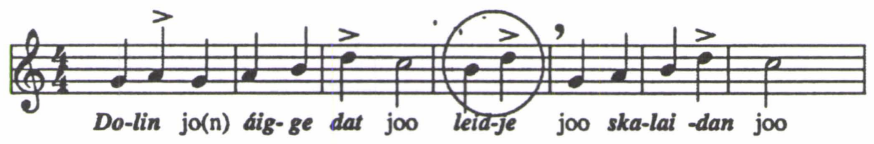

Guhtura-Niillas' Ante's luohti written according to the yoikers accents:

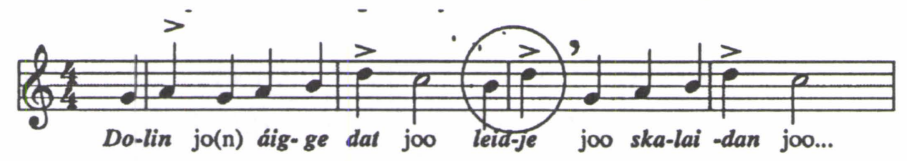

Note example 3. Comparison of the Guhtura-Niillas' luohti and Guhtura-Niillas'Ante's luohti.

\section{2) The joint in the Guhtura-Niillas' luohti and Guhtura-Niillas'Ante's luohti}

Where does the joint belong in these luohtis? In the meter of the text the joint is at the beginning of a line. According to the melodic motives, the joint can be analysed in two different ways. In Guhtura Niillas' luohti the joint is a repetition of the third motive of the whole luohti (d-c).

In Guhtura Ante's luohti it is more clear that the joint resembles the first melodic motive of the whole luohti (b-d = g-b). According to the yoiker's accents, the joint is in the middle of two melodic variations so the joint is the connector of two melodic lines. Although there is a difference in the motive of the joint, the joint hasa similar function in both of the luohtis (see note ex. 3.). 


\subsection{Guhtura-Niillas' luohti in the Launis' collection}

Armas Launis (1908) gathered a large collection of luohtis during his two trips to Northern Lapland in 1904 and 1905. The collection contains over 600 transcribed luohtis. Unfortunately no recordings of this material exist. Furthermore there is a lot of information missing from this collection, mainly variations of the melody of the yoiks, ornamentations, possible changes in the interval structure and the whole texts of the luohtis.

There are four examples of Guhtura-Niillas' luohti in the Launis' collection. Example number 550a was collected from an unknown person from the river Deatnu in the district of Utsjoki; 550b from a reindeer Sámi called Jouni Aikio (better know as Kaapin Jouni) from Bátnejávri in the district of Inari; 663a was collected from a reindeer Sámi called Aslak Jomppanen from Menesjávri in the district of Inari; 663b was collected from a fisher Sámi called Matti in Menesjávri in the district of Inari.

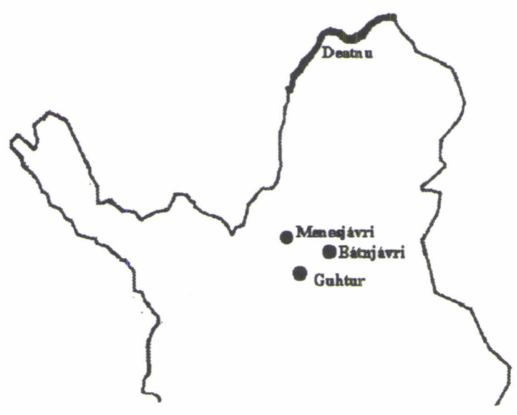

Figure 2. Map of the places where the yoiks were collected.

The first version of luohti has four text lines from which the first contains the name of the yoiked person (Nils Guttur) and the third a description of him. The second and fourth text lines are filling syllables (la lai-la lai-la la). It is to be noted that Niillas' name is in its Norwegian form Nils Guttur. Here Guttur refers more to Niillas' father's name than the village Guhtur. This is understandable because Guhtur as a name of the village was not widely known in the early years of the 20th century. The words in the second text line gadg'gir go èavra are difficult to translate; first because the mentioned incident in Niillas' life is not yet known, secondly Launis did not know the Sámi language well enough, and thirdly because the writing system of the Sámi language was not standardizied. The second line means probably hard as a stone.

Text example 3. Launis 1908, p. 136, example number 550, a.

\begin{tabular}{|l|c|c|c|c|c|c|c|c|c|c|c|c|}
\hline \multicolumn{10}{|c|}{ The text } & English translation \\
\hline Nils & Gut- & tur & dal & de & maid & la & lai- & la & lai- & la & la & $\begin{array}{c}\text { Nils Guttur (Guhtura- } \\
\text { Niilla), now, here he is }\end{array}$ \\
\hline gædg'- & gir- & go & čæv- & ra & de & la & lai- & la & lai- & la & la. & (hard as a stone) \\
\hline
\end{tabular}


In this version of the luohti, there is the same melody ${ }^{9}$ as in later performances, but the characteristic beginning motive (g-h-g), which can be found in other versions, is missing as well as the tail motive. All the melodic lines are identical though there are variations in the text. Each of the lines consists of the center motive (SSS SSS).

Table 5. The possible syllabic combinations in different melody lines.

\begin{tabular}{|c|c|c|c|c|}
\hline Line: & \multicolumn{4}{|c|}{ Note durations: } \\
\hline & B & & & $\mathrm{T}$ \\
\hline $1,2,3,4$ & - & SSS & SSS & - \\
\hline
\end{tabular}

The accent is most probably on the second beat of the melody because Launis has marked the barline in front of this note. There are no notes that could be analysed as a joint motive. The breathing pauses are in clear places, and they do not disturb the rhythm or the pulse of the yoik.

Original version

Utsjoki 1904-5 (Launis 550, a)
Interpretation

According to the similar melodical phraces

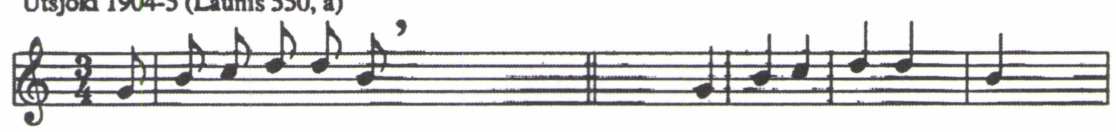

Note example 4. Launis 1908, p. 136, example number 550, a.

The text of the second version in the Launis collection contains only the name of Guhtura-Niillas (Kuttura Nilla) and the filling syllables (lul-lu gul). This is repeated three times. The beginning motive comes from the three syllable word Kut-tu-ra. The tail motive can be analysed as a joint motive, although it has only one note.

Text example 4. Launis 1908, p. 136, example number 550, b.

\begin{tabular}{|l|l|l|l|l|l|l|l|c|}
\hline \multicolumn{7}{|c|}{ The text } & \multicolumn{2}{c|}{ English translation } \\
\hline Kut- & tu- & ra & Nil- & la & lul- & lu & gul, & Guhtura-Niillas \& (filling syllables) \\
\hline Kut- & tu- & ra & Nil- & la & lul- & lu & gul, & “ \\
\hline Kut- & tu- & ra & Nil- & la & lul- & lu & gul. & “ \\
\hline
\end{tabular}

The melody of this version is almost identical to the later performances of Niillas' and Ante's yoik. This time Launis has even marked the accent on the second beat. The three syllable beginning motive (g-h-g) exists as well as the centre motive and the tail motive (SS SSS SL S) (see table 6).

\footnotetext{
${ }^{9}$ Launis uses different time signatures in his transcriptions. To make the comparison easier I have modulated the melody to a similar paradigmatic form as I have used in the analyses of Guhtura-Nilla's and Ante's yoiks. The original is shown as well.
} 
Table 6. The possible syllabic combinations in different melody lines.

\begin{tabular}{|c|c|c|c|c|}
\hline Line: & \multicolumn{4}{|c|}{ Note durations: } \\
\hline & B & \multicolumn{2}{|c|}{ C } & T \\
\hline $1,2,3$ & SS & SSS & SL & S \\
\hline
\end{tabular}

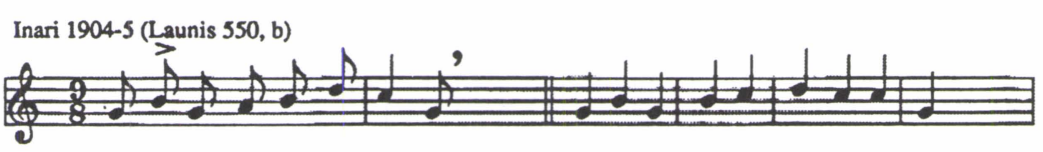

Note example 5. Launis 1908, p. 136, example number 550, b.

The text of the third version contains once again only the name of the object and the filling syllables (Guttur Nila lol-lol...).

Text example 5. Launis 1908, p. 166, example number 663, a.

\begin{tabular}{|l|l|l|l|l|l|l|l|c|}
\hline \multicolumn{7}{|c|}{ The text } & English translation \\
\hline Gut- & tur & Ni- & la & lo- & lol- & lo & lol- & Guhtura-Niilla \\
\hline lo & lol- & lo & lol- & lo & lol- & lo & lo. & (filling syllables) \\
\hline
\end{tabular}

The melody can be analysed as a narrowed melody by its ambitus (from g-d to g-b) when it is compared to other variants. The melody does not climb to $\mathrm{c}$ or $\mathrm{d}$ but stays in b. The most remarkable feature of this version is the repeating SL -rhythm. The beginning motive is reduced to two notes because the word Guh-tu-ra is narrowed as well to a two syllable form Gut-tur. The fact that the second syllable is long and in fact it occupies the whole time of the three-syllable beginning motive is also notable. Once again there is an accent on the second syllable (see table 7). The text line and melody line are overlapping as well.

Table 7. The possible syllabic compinations in different melody lines.

\begin{tabular}{|c|c|c|c|c|}
\hline \multicolumn{1}{|c|}{ Line: } & \multicolumn{3}{|c|}{ Note durations: } \\
\hline & B & \multicolumn{2}{|c|}{ C } & T \\
\hline 1,2 & SL & SL SL & SL & S \\
\hline
\end{tabular}

Inari 1904-5(Launis 663, a)

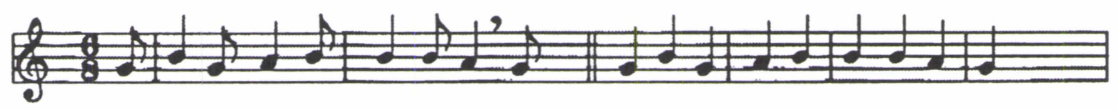

Note example 6. Launis 1908, p. 166, example number 663, a.

In Launis $663 \mathrm{~b}$, the text consists of the name Guttur Nila and the filling syllables (nun-nu...). Jorgu turga possibly means that Niillas wore a fur coat from which the hairside was turned inside or it can mean the whole skin of an animal. 
Text example 6. Launis 1908, p. 167, example number 663, b.

\begin{tabular}{|l|l|l|l|l|l|l|l|l|}
\hline \multicolumn{7}{|c|}{ The text } & \multicolumn{2}{c|}{ English translation } \\
\hline Gut- & tur & Ni- & la & nun- & nu & nun- & nu & Guhtura-Niillas \& (filling syllables) \\
\hline jor- & gu & tur- & ka(n) & nun- & nu & nun- & nu. & (a fur coat with the hair turned inside) \\
\hline
\end{tabular}

This version is interesting because at the first glance this version seems to differ a lot from the other known versions of Guhtura-Niillas' luohti. It is the only version of Guhtura-Niillas' luohti in the Launis' collection with the third degree transcribed as a minor. Also the melodic line seems to be somehow different.

The problem of the different melodic line can be solved in two different ways. If the place where the melody begins is changed, we find that also this version starts to resemble the other versions. If we think that the last note $(\mathrm{g})$ of the melodic line is really the first of the first phrase, we will get a melody which begins with one jump upwards from $\mathrm{g}$ to $\mathrm{d}$ and another jumps downward from $\mathrm{d}$ back to $\mathrm{g}$.

But when we listen to the recorded versions on the same yoik it is not always certain that the third degree of the scale should be analysed as major instead of minor. Sometimes the interval between the tonic and the third degree is almost a fourth. In this version only three different pitches are used $\mathrm{g}, \mathrm{b}$ and $\mathrm{d}$ but the melodyline seems to follow the already known shape of Guhtura-Niillas' luohti (see note ex. 7.). In this transcription it is also possible to find the joint which is the extra note $\mathrm{g}$ in the end of the melody.

It is known that in luohtis sometimes even the text moves in relation to the melodic line (Saastamoinen 1994, 39). The yoiker has started the melody from the second note, but the words from the beginning. So, the yoiker has turned the pulse of the luohti like the object of the luohti has turned his fur-coat.

Table 8. The possible syllabic combinations in different melody lines.

\begin{tabular}{|c|c|c|c|c|}
\hline \multicolumn{1}{|c|}{ Line: } & \multicolumn{3}{|c|}{ Note durations: } \\
\hline & B & \multicolumn{2}{|c|}{ C } & $T$ \\
\hline 1,2 & {$[S]+S$} & $S+S+S$ & $S+S$ & $S$ \\
\hline
\end{tabular}

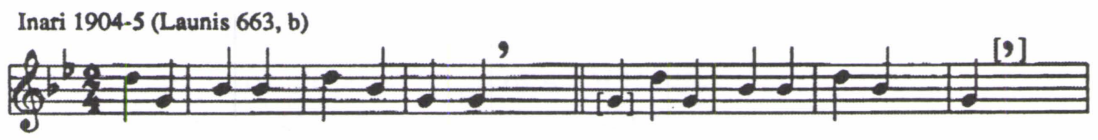

Note example 7. Launis 1908, p. 167, example number 663, b.

\section{Conclusion}

In this paper I have discussed some features of the yoik, which I believe show that the traditional Sámi yoikers have both a strong sense and knowledge of the yoik tradition, 
as well as an intention to interprete the luohtis with individual freedom. Each of the analysed versions of Guhtura-Niillas' luohti has its unique features, sometimes so strong that the original melody seems almost to disappear. With analysis I have shown the similarity of these different versions when the melody, text and meter are considered. Despite all the differences, it is clear that they function with similar logic.

In analysis, the most interesting finding was that although there is no external pulse to which the yoiker could oppose him or herself (like in the Western music), a yoiker can utilize three kinds of internal meters already inherent in the yoik:

1) the meter of the melody

2) the meter of the text

3) the yoiker's individual idea of interprating the rhythmic manifestation of the meter and accentuation, which is heard in the way he or she makes accents. In some performances there can also be heard an additional pulse of yoiker's feet.

Furthermore, the key-point in the question of how these three overlapping metrics can work together is the joint between the melodic phrases in sequence. It can be analysed differently from the point of view of all the different metrical levels. It is often said that yoik has no beginning or end, it only is there. As the different versions of the Guhtura-Niillas' luohti show, it is the flexibility of the joint and the playing with different metrics, which makes the idea of everlasting sequence possible.

In order to understand the yoik it is important to try to find out which elements in the melody and text identify a certain yoik. It is clear that by comparing several versions of the same yoik we can achieve a much clearer picture of the forms a yoik can take.

How is it, then, possible to yoik different peoples with the same yoik? This question still remains although some answers can be found. The object of a luohti can be identified with different lyrics as was shown in the comparison of Niillas' and Ante's luohtis. Musically these two luohtis were so close to each other that no significant differences could be found. Maybe inherited luohtis do not change much, although the objects change. At least the family does not change.

Still change is natural to the yoik. All the different analysed versions show that there is no sense yoiking in exactly same way as someone has done already. Individuality has been important because it is a question of personal communication. Difference is expected.

Even the idea of similarity in different versions is strange to Sámi culture. There were no recording devices that would have made it possible to repeat a yoik over and over again and to learn it that way. Memorizing was important. Sometimes a yoik has been performed only once. Although there is evidence that memorizing was done more efficiently through oral transmission then than in nowadays literal societies.

The traditional yoik is a form of a multilevel communication. It cannot be viewed apart from its original performance situation and participants without losing its meanings. Some yoikers say that everything in human life can be expressed through the yoik. 


\section{References}

Archive tapes

Guhtura-Niillas' luohti recorded by Erkki Ala-Könni in Inari 1961. Tape A-K 544/5, Collection of the archives of the Department of Folk Tradition. University of Tampere.

Guhtura-Niillas' Ante's luohti recorded by Erkki Ala-Könni in Inari 1961. Tape A-K $547 / 3$, Collection of the archives of the department of Folk Tradition. University of Tampere.

An interview of Magga, Niila (Guhtura-Niillas(a) Niillas) made by Erkki Ala-Könni in Inari 1961. Tape A-K 545/1-2, Collection of the archives of the department of Folk Tradition. University of Tampere.

\section{Literature}

Aikio, S. \& Aikio-Puoskari, U. \& Helander, J. 1994. The Sami Culture in Finland. Lapin sivistyssera. Helsinki.

Aikio, M. 1987. "Saaritunturien saamelaiset." Pohjolan Saamelaiset. - Sovinnolliset sopeutujat. Toim. Huopainen, R. Lapin maakuntamuseon julkaisuja 7, p. 17-37. Oulu.

Edström, K.-O. 1978. Den Samiska Musikkulturen. En Källkritisk Översikt. Skrifter från musikvetenskapliga institutionen, Göteborg: 1.

Jouste, M. 1997. Ei tarvitse väistyä, jos osaa sopeutua. Kutturan lapinkylän asutus ja kulkuyhteydet. Suomen historian proseminaarityö. Tampereen yliopisto.

Launis, A. 1908. Lappische Juoigos-Melodien Gesammelt und Herausgegeben. Suomalais-ugrilaisen seuran toimituksia XXVI. Helsingfors.

Lehtola, V-P. 1997. Saamelaiset, yhteiskunta, taide. Kustannus-Puntsi. Jyväskylä. Lippus, U. 1995. Linear Musical Thinking: A Theory of Musical Thinking and the Runic Song Tradition of Baltic-Finnish People. Tallin: AS Pakett.

Magga, T. 1994. Giellamolsun ja áddemiella Manin Guhtura Sámit dál suomastit? Festskrift til Ørnulv Vurren Særtrykk. Tromsø Museums Skifter XXV Tromsø Museum Universitet I Troms $\varnothing$.

Nahkiaisoja, T. 1995. Inarin pitäjän asutuskehitys vuosina 1805-1910. Suomen ja Skandinavian historian pro gradu-tutkimus. Oulun yliopisto.

Niemi, J. 1998. The Nenets Songs. A Structural analysis of text and melody. Acta Universitatis Tamperensis 591. Tampere.

Saastamoinen, I. 1994. Rytmikaava-ajattelu saamelaismusiikin hahmotusmallina. Näkökulma joiun muotorakenteiden ja leu'dd-improvisaatioiden analyysiin. Musiikkitieteen pro gradu -tutkielma, Jyväskylän yliopisto.

Tikkanen, H. 1966. Lapin pohjoisrajan kysymyksiä 1800-luvulla. Lapin tutkimusseuran vuosikirja VII 1966. Toim. Juhani Nuutilainen. Rovaniemi. Turi, J. 1979. Kertomus saamelaisista. Saamen kielestä suomentanut Samuli Aikio.WSOY Porvoo. Alkuteos: Muittalus samid birra (1910). 